\title{
Question-asking behavior as a form of cognitive activity in primary school children
}

\author{
Elvira A. Baranova ${ }^{\mathrm{a}}$, Evgeni L. Nikolaev ${ }^{\mathrm{b}^{*}}$ \\ ${ }^{a}$ Social and Clinical Psychology Chair, Chuvash State Pedagogical University, \\ Cheboksary, Russia \\ b Developmental and Special Psychology Chair, Ulianov Chuvash State University, \\ Cheboksary, Russia
}

* Corresponding author. E-mail: pzdorovie@bk.ru

Children's questions are an indicator of active cognitive perception of reality. Questions but not answers are relevant in revealing a child's mental life, consciousness and thinking. The lack of question-asking skills can hinder learning, searching and exploration in children. To determine in 7- and 8-year-old school children the common and variable peculiarities of designing a search process for necessary information concerning an unknown object by volitionally formulated questions, as well as the dynamics of the questioning process throughout a school year. The study was based on an experimental methodology, codenamed Guess what there is in the box, and was conducted in four schools in Cheboksary. The sample comprised 158 primary school first-graders who took part in a confirmatory experiment twice, once in September and once in May. The research showed that $96.3 \%$ of the questions asked were search questions. Only $30 \%$ of the first-graders initiated their searching activities of their own will without having to resort to the given search algorithm, while $70 \%$ did not begin asking questions without outside stimulation. The analysis of the dynamics of children's question-asking behavior exhibited a tendency to decrease in a number of questions asked over the course of the school year. Primary school children need psychological and pedagogical scaffolding aimed at developing a question-asking behavior as a form of cognitive activity to achieve a possible age potential in development.

Keywords: cognitive activity, question-asking behavior, primary school children, types of children's questions 


\section{Introduction}

Children's questions are justly considered to be an indicator of their active cognitive perception of the reality, as well as of their mental development, thinking abilities and growth. It is not answers but questions that are more relevant in revealing a child's mental life, consciousness and thinking, and they are the most evident indicator of a child's thinking at early stages (Rubinstein, 2008). The process of question-making by children reflects their mentality, depth and clearness of understanding the matter. Questions are also a means of perceiving the surrounding reality and satisfying the need for cognizing it.

Educators have understood the importance of question-asking behavior for decades (Fahey, 1942; Dillon, 1982; McManis \& Gunnewig, 2012). Children's question-asking behavior is closely connected with learning activities such as reading. It has experimentally been proved that not only the content of the questions asked but also their type depend on the goal of reading, which can be subdivided into comprehensive reading and problem-solving reading (Ishiwa, Sanjosé, \& Otero, 2013). Such activity plays a significant role in teaching mathematics (Foster, 2011) and teaching students to think scientifically (Maskill \& deJesus, 1997; Gillies, Nichols, Burgh, \& Haynes, 2012; Craft, Cremin, Hay, \& Clack, 2014). Cognitive activity is also a predictor of success in language learning (Verbitskaya, Malykh, Zinchenko, \& Tikhomirova, 2015). Teachers' awareness of these and other peculiarities of cognitive activity of their students demonstrates their professional qualifications (Drovnikov et al., 2016, 2016).

Question-asking behavior in the process of learning can also reflect a pupil's cognitive inactivity, which can depend on their age, gender, and the teacher's appraisal of their achievements (Good, Slavings, Harel, \& Emerson, 1987). Research involving children's mothers who had intentionally encouraged their children to ask questions revealed a favorable influence on school first-graders' question-asking behavior (Henderson, \& Garcia, 1973). Studying the question-asking behavior of school children can also be used by teachers to define the problems they can face while teaching a child (Maskill, \& deJesus, 1997). The importance of questionasking behavior in the cognitive development of a child has also been confirmed by work with children suffering from autism spectrum disorders. The research has singled out special forms of interventions that can help improve the question-asking skills of autistic children (Raulston et al., 2013). Contemporary studies of questionasking behavior as a form of cognitive activity show that turning to advanced communication technologies, for example, micromessaging in the microblog format, noticeably stimulates question-asking behavior in the process of learning, when the number of questions and their variety are significantly growing (Ledford, Saperstein, Cafferty, McClintick, \& Bernstein, 2015).

The works of many researchers present findings concerning the influence of children's question-asking behavior on their cognitive activity. It was established that children's cognitive activity corresponds to three types of question-asking behavior-having no questions, asking questions for general information, and asking questions for specific information (van der Meij, 1990).

Scientists have conducted comparative research of question-asking behavior of school children belonging to two different generations more than thirty 
years apart. Their findings reveal minor changes in the processes of children's individual development underlying this form of cognitive activity (Meyer, \& Shane, 1973). Children's question-asking behavior as a form of cognitive activity has also been studied in the context of gender specificity (Meyer \& Shane, 1973; Good, 1987), as well as within the framework of ethno-cultural differences (Heath, 1982).

At the same time, there is practical evidence that junior primary school children feel reluctant to ask questions, and the number of questions asked falls as children approach school age (Hurlock, 1956; Jersild, 1968). Children have difficulty asking questions on intentional request, such as in a problem situation, based on a text, or regarding some other learning matter. When making questions, children revealed a tendency towards stereotyping, i.e., either asking single-type questions or hiding a different cognitive meaning behind typically formulated questions (Tarasova, 2004; Shumakova, 1985). A lack of questionasking skills can hinder learning, searching and exploration, all of which require prior hypothesizing, etc.

Notwithstanding the attention that the issues of development of children's cognitive activity have received from scientific research by Russian and foreign psychologists for many decades (Piaget, 1994; Alves, 2014; Krichevets, 2014), the issue of children's question-asking behavior as a form of cognitive activity has long escaped the attention of researchers. Most available studies on this psychological issue can be divided into two groups. The first group targeted their research at studying spontaneous questions asked by children in their childhood (Sorokina, 1945; Hurlock, 1956; Ramonova, 1961; Sirbiladze, 1966; Jersild, 1968; Mosher, \& Hornsby, 1971; Babich, 1984; Piaget, 1994; Yushkov, 1997; Rubinstein, 2008; Komarova, 2011, etc.). The second group includes only a few research works that studied peculiarities of the questions asked in the situation when examinees had to volitionally formulate questions, i.e., "forced questions" (Henderson, \& Garcia, 1973; Shumakova, 1985; Good et al., 1987; van der Meij, 1990; Yushkov, 1997; Tarasova, 2004, etc.).

The first Russian psychologist to study children's questions experimentally was A. I. Sorokina (1945). This analysis of 4,000 questions asked by preschool children of various ages allowed the author to classify the questions according to their underlying motives. Later, based on the orientation of children's questions toward certain phenomena of reality and their depth of knowledge about it, multiple types of cognitive interest in preschool children aged 3-8 were established (curiosity, inquisitiveness, and intellectual interest).

Overall, the available works devoted to this subject report on several important aspects of the children's question-asking behavior as a form of cognitive activity: the content and orientation of the questions; their typology; their quantitative and qualitative dynamics in the preschool and primary school age; and the possibilities and conditions of increasing children's question-asking activity.

At the same time, it is possible to state that such research mostly covers the questioning peculiarities of preschool children or more senior school children. Very few scientific research works have studied primary school children. Noteworthy among these are studies conducted by N. B. Shumakova (1985), who sig- 
nificantly contributed to the investigation of children's question-asking behavior. She established the key functions of questions in a mental activity (reflexive, regulating, stimulating, the function of highlighting and recording the unknown, and the function of completing the information); suggested a set of original diagnostic tools that help study the questions asked by children in a problem situation; laid down an extensive classification of questions according to their function-and-content characteristics; distinguished types of task setting and solution finding in a problem situation (problem-oriented and descriptively practical); and noted certain specific features of question-asking behavior of preschool children and primary school children.

Among recent works, several are devoted to studying only certain aspects of the issue of children's question-asking behavior:

- the analysis of the content- and genetic-oriented peculiarities of the questions arising in primary school children in the process of dialogical subject teaching in their first three school years (Yushkov, 1997);

- the description of an original methodology of studying question-asking behavior in the process of comprehending a text; a classification of questions according to a cognitive meaning; and detection of the questions' specificity in a multi-level context, such as their shallow nature and low level of generalization; and their structuring based on echolalia, stereotypes, and patterns (Tarasova, 2004);

- the analysis of search questions asked by $3^{\text {rd }}$ - and $4^{\text {th }}$-grade school children and the revelation of the dominance of the questions associated with a zeal for investigating the objects and phenomena of the surrounding world and the material life of people (Komarova, 2011).

The analysis of scientific literature reveals a rather stable interest in studying question-asking behavior in learners. At the same time, less attention is drawn to primary school children, who have just started systematic learning. In addition to that lack of focus, a complete lack of attention is found regarding issues of manifestation of school first-graders' question-asking behavior as a form of cognitive activity in situations where they are given a special task to search for something unknown.

Collecting such data using cultural-historical theory as a methodological framework for the research can help define common difficulties in implementing verbal cognitive activity, elucidate the peculiarities of search process design in a problem situation, and determine proximal possibilities for realizing age potentials in this sphere of psyche. The concept of the zone of proximal development can provide a psychological foundation for working out efficient psychological measures for intensifying primary school children's question-asking behavior as a form of their cognitive activity.

Following what has been mentioned above, the research objective has been set as follows: to determine in 7- and 8-year-old school children common and variable peculiarities of designing a process of search for necessary information concerning an unknown object by volitionally formulated questions, as well as their dynamics throughout a school year. 


\section{Method}

The research was conducted in four general secondary schools located in the city of Cheboksary. The sample comprised 158 primary school first-graders aged 7-8. Overall, 76 boys (48.1\%) and 82 girls (51.9\%) took part in the confirmatory experiment. The study of cognitive activity of children was conducted twice, once at the beginning of the school year (September) and once at the end of it (May).

The given research involved the following methods: analysis, generalization and systematization of the research data and concepts; working out the content and procedure of the diagnostic methodology for studying the cognitive activity in the form of questions; confirmatory experiment; quantitative and qualitative data analysis; and description and interpretation.

The study was based on an experimental methodology codenamed as Guess what there is in the box. Each child was set a goal to discover what object was in the box by asking questions. A box containing a simply configured object that children see quite often in their everyday lives (e.g., an apple, a pencil, a pen, an eraser, a handkerchief, etc.) was set in front of the child.

At first, the child was given the chance for an independent guess. The child was asked, «Do you want to learn what there is in the box? You must ask questions to learn what object there is in the box. You may ask any questions you like; I will answer your questions so that you are able to guess what is in it».

However, when the child asked particular questions regarding the object in the box (e.g., Is this an apple? Is this a pencil?), the experimenter suggested a readymade search algorithm based on several questions. «Ask me: What is this object needed for? What is done with it? What is it made of/from? What form does it have? What size is it? What color is it?». Such help was designed to determine a child's proximal potential to master an efficient strategy for seeking necessary information about the object.

In case the child ignored the suggested way of solving the problem, another attempt was made to direct the child's thought along the needed course.

The child was to solve the task within 10-15 min. So as not to exhaust the child, the activity was terminated under any pretense towards the end of the allotted time.

This design of the research procedure solved two diagnostic tasks, the necessity of which was proved by L. S. Vygotsky (Vygotsky, 1984): determination of a child's actual potential and their zone of proximal development in the aspect of psyche under study.

The questions asked by children when performing the diagnostic task were recorded and later classified into groups according to our typology (Baranova, 2009). Figure 1 presents the typology of questions used by children in the experiment.

I. Search questions - a form of verbal searching (exploratory) activity arising in the case of insufficient information regarding the object and aimed at gaining necessary information about it. This activity includes four groups of questions, each having subgroups of questions of various direction:

1) Productive questions, which are directed at obtaining information and which require an answer. As per the search target, this group includes the following types of questions: 


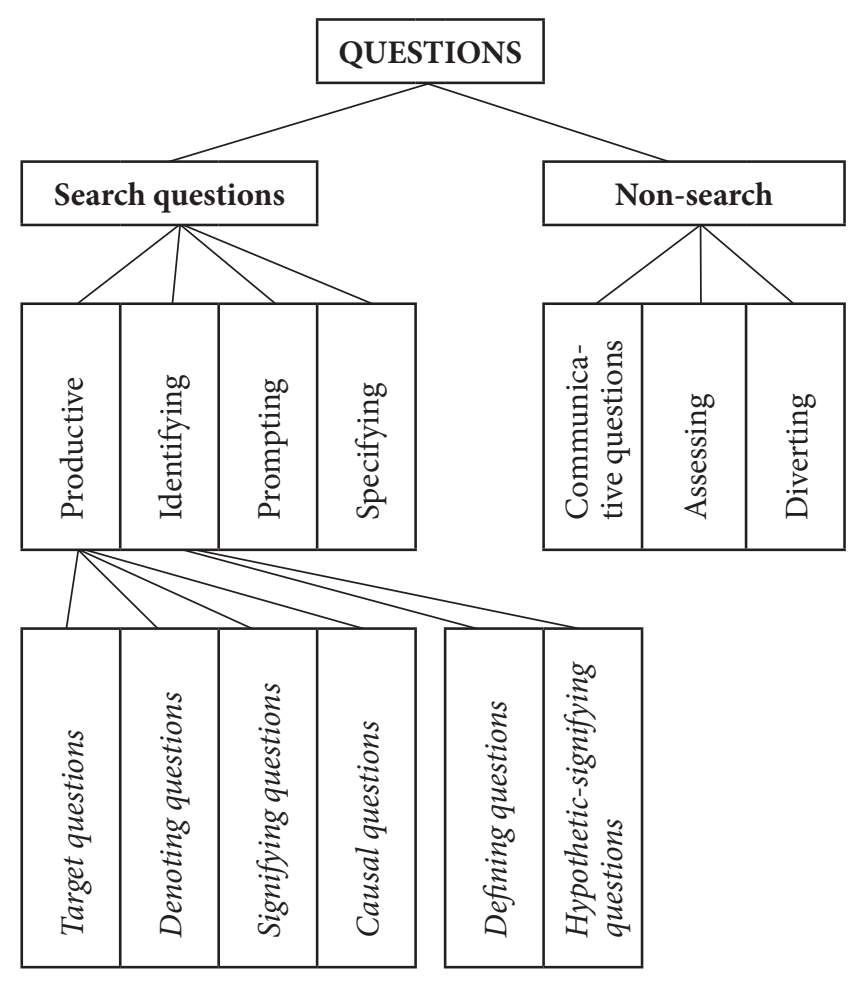

Figure 1. Structure of questions used by children

- target questions, which determine the purpose, application and function of the object (What... for? Why.? Who needs it?);

- denoting questions, which aim to establish the denotation of the object (What is it?);

- signifying questions, which are asked to determine the object's possible features-properties, attributes, location, etc. (What kind.? How much/ many? Where.?);

- causal questions, which aim to establish the interrelation of the object with other objects, as well as the design and the configuration of the target object (Why.? How.? What is it associated with? What parts does it consist of?);

2) identifying questions, i.e., particular hypotheses in the interrogative form, which are directed at identification of the object and its features. This group may have two subgroups of questions: defining questions, which put forward particular hypotheses concerning the object (Is it.?), and hypothetic-signifying ones, i.e., hypotheses concerning the properties and other features of the unknown object (Is it of... color? Does it have a... form? Does it grow in ...?);

3) prompting questions, which are aimed at completing the prompting information (What letter does it start with? How many letters are there in the word?);

4) specifying questions, which are asked to specify what is needed to perform the search task (What do I need to do? How many questions may I ask? What kinds of question may I ask?). 
II. Non-search questions mean no search for necessary cognitive information, and they include the following:

1) Communicative questions, which help establish and continue communication with the experimenter;

2) Assessing questions, which aim to assess the performed activities and can be asked either to the experimenter or to the examinees themselves;

3) Diverting questions, which take a special place in the row of non-search questions. For their content, they are quite far from seeking the set goal of identifying the unknown object. Instead, they testify that children do not understand the essence of the cognitive goal set before them ("How much is twice two?").

Quantitative and qualitative characteristics of questioning activity in children served as the main outcome measure. Statistical analysis of the data received was performed using t-test for mean and standard deviation and $\mathrm{z}$-test for proportions with p-value less than 5\%. All analyses were conducted using Statistica, version 10 .

\section{Results and discussion}

When studying the cognitive activity in the form of questions (search and nonsearch questions), the first type of questions was the special focus, as this is the group of questions that presents a form of verbal searching (exploratory) activity, which begins in the case of insufficient information about the target object and which is aimed to obtain the necessary information about it.

Table 1. Representation of search questions asked by children

\begin{tabular}{|c|c|c|c|}
\hline Question group & $\%$ & Question subgroup & $\%$ \\
\hline \multirow[t]{4}{*}{ Productive questions } & 47.2 & Target questions & 12.6 \\
\hline & & Denoting questions & 2.0 \\
\hline & & Signifying questions & 27.8 \\
\hline & & Causal questions & 4.8 \\
\hline \multirow[t]{2}{*}{ Identifying questions } & 50.8 & Defining questions & 32.9 \\
\hline & & Hypothetic-signifying questions & 17.9 \\
\hline Prompting questions & .7 & - & - \\
\hline Specifying questions & 1.3 & - & - \\
\hline
\end{tabular}

The research showed that the overwhelming majority of the questions (96.3\%) asked by the children were search questions, which proves the children's awareness of the cognitive task set before them and their ability to direct all their searching activities towards performing it. At the same time, only $30 \%$ of the first-graders initiated their searching activities of their own will without having to resort to the given search algorithm, while most of the children (70\%) did not begin asking questions without outside stimulation, which confirms that most first-graders have low cognitive activity. However, when the children were given a list of ques- 
tions to help them guess the target object, they realized the necessity of seeking the information in a certain sequence - from the purpose of the object to its certain external features - within a sufficiently rapid period. On average, 7.9 questions were asked in the process of seeking necessary information about the target object. The data on groups and subgroups of search questions are given in the following table.

Thus, within the search questions, there is an insignificant gap between the numbers of productive questions (47.2\%), which were the most effective in search, and the identifying ones (50.8\%), which were particular hypotheses aimed at identifying the target object and its features. At the same time, this ratio shows that children do not always manifest their ability to ask those questions that help to discover the application and characteristic features of the invisible object.

Within the productive questions, the biggest subgroup comprised signifying questions (27.8\%), which help discover the object's likely features - properties, attributes, location, etc. Target questions, oriented at finding out the application of the object and its function, made up a relatively small part (12.6\%); causal questions, which help to determine the configuration of the target object and the interrelations between its constituent parts, have no reason to be regarded as widely spread (4.8\%). The meagre percentage of the denoting questions (What is it?) just $2 \%$ - vividly demonstrates that the overwhelming majority of the examinees realizes the necessity of determining the particular features of a target object and do not even conceive of asking such questions to denote the concealed object.

Within the identifying questions, the definitions (32.9\%), which were particular hypotheses (Is it a...?), occupied the leading position. Next came the hypothetic-signifying questions $(17.9 \%$ ) that hypothesize what properties and other features the unknown object might have (Is it red? Is it round? Does it grow in the kitchengarden?). Single cases (.7\%) occurred when children guessed at the object with the help of prompting questions (How many letters are there in the word? What letter does it start with?), which can be associated with the children's learning reading a new sphere where they can apply their minds.

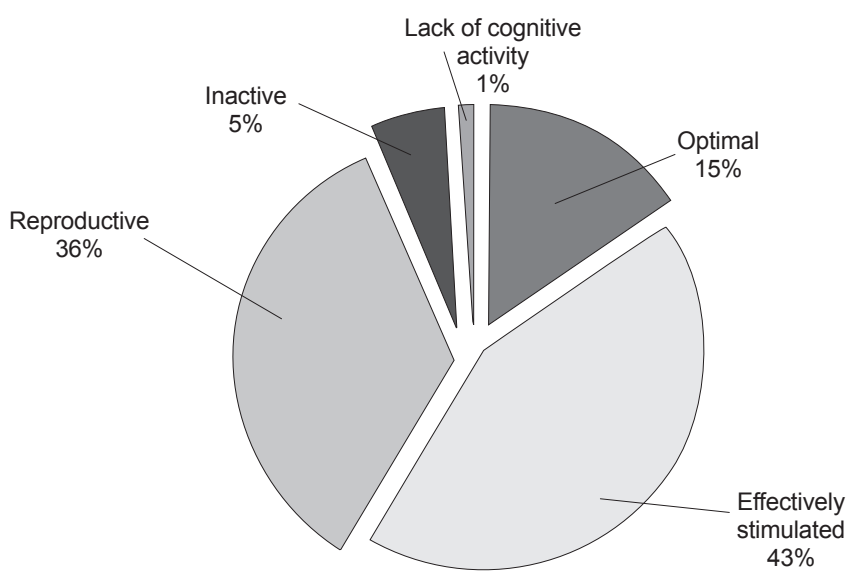

Figure 2. Distribution of the children according to the level of their question-asking behavior (\%) 
Alongside with characterizing the quantity and content of the questions, the peculiarities of children's strategy formation for seeking the information about the unknown object, as well as the manifestation of their activity in the search process, were analyzed. (Figure 2).

When determining the level of the development of question-asking behavior as a form of cognitive activity, we assessed such parameters as readiness for mental strain, eagerness to find a solution to a problem, zeal for independence, and a major action strategy. The major action strategy was assessed according to the following scale:

- tendency to act with the help of productive questions based on the independently made and clearly defined search algorithm;

- the same tendency, but based on the outside algorithm;

- adherence to a mix of productive and identifying questions;

- zeal for searching activity that is mostly based on the hypotheses, with their number equaling or exceeding 8 ;

- the same tendency, but with the number of hypotheses below 8 , with a minimum of $1-2$.

At the optimal level, fixing the possible potentials of primary school age, children showed high interest for question-based search, efficiency of activity, and pronounced independence in solving a problem. Within this group, there were two clearly distinguished subgroups of the examinees. The children in the first subgroup (5.7\% of the total number) exhibited the ability to choose their own search strategy quite independently and showed a tendency to act based on productive questions (the ratio of productive questions to the identifying ones is 4.5 to 1 ). The other first-graders (9.5\%) showed inefficient initial activities: the children gave particular hypotheses concerning the target object and its properties, which deterred them from finding the information needed for guessing the unknown object. After being offered a list of possible questions that was intended to help arrange the search in a certain sequence, the children started acting in a cardinally different way: their search became target-oriented and it was based mainly on productive questions. Additionally, children thoroughly premeditated the wording of their questions. This subgroup showed a higher use of identifying questions compared to the productive questions, with a corresponding ratio of 2.4 to 1 .

The following level of development-effectively stimulated-was revealed in $43 \%$ of the first-graders, who showed a typically more or less defined activity towards guessing the invisible object and the activity efficiency. At the same time, there are various noteworthy approaches to performing the diagnostic task, depending on the nature of help offered to the children and the specificity of compliance with the given search algorithm.

Among the typical peculiarities of approach $A$ (29.4\% of children at this level) were the children's acceptance of the suggested way of seeking the unknown, variety of question wording, and search efficiency. However, compared to the children demonstrating the first level of development, they showed a lower zeal for asking questions, which required stimulation by the experimenter (e.g., "Ask another question" and "Ask me about the object lying in the box).

Approach B (51.4\% of schoolchildren at this level) was employed by the examinees whose searching activity complied with the search strategy suggested by the 
experimenter, but only after the second presentation of the line of action, not from the very start. Furthermore, these children were noted to digress from the given algorithm, to shift to inefficient search based on identifications and to repeat the questions that had already been answered.

Approach $C$ was used by $19.2 \%$ of the children, who ignored the suggested algorithm. They notably adhered to hypothesizing about the object and its properties (2.5 identifying questions to 1 productive question). Moreover, the content of the information discovered by these children in their search was quickly forgotten. Focusing the children's attention on the known information alongside the generalization of the details found in cooperation with the experimenter made achieving the result possible.

The third, or reproductive, level was achieved by $35.4 \%$ of the first-graders. The strategies of their activities were characterized by tendency towards searching activity based on identifying questions (the ratio of identifying questions to productive ones is 1.4 to 1 ). However, it would be more correct to identify the choice of productive questions as imitation of the adults' line of action: such questions were asked in the sequence chosen by adults. There were single cases in which children succeeded in solving the problem; however, the solution was more often the result of the experimenter driving children towards a certain thought ("What do we use to write on the paper?") than the result of their own searching activity.

The inactive level, distinguished by weak activity, was achieved by only $5.1 \%$ of the children. Among the common features of such activity were children's greater interest for the experiment itself than the search process, reluctance to obtain a result, inactivity, lack of initiative in asking questions, inclination for long pauses, inability to follow the work mode that had been offered from outside, feeling relief after the end of the class, and dominance of identifying questions over the productive ones ( 7.6 to 1 ), with a clearly marked tendency to use more definitions than hypothetico-signifying questions.

The fifth level demonstrates lack of zeal and actual inability of the first-graders to perform a searching activity in the form of questions. However, this level was achieved by only two children (1.3\%).

The analysis of the dynamics of question-asking behavior as a form of cognitive activity throughout the year showed a drop, to 7.3, in the average number of questions asked by the children, as shown in table 2 . This result testifies to the data obtained by developmental psychologists on the tendency to a decrease in the number of questions asked by children aged from 6 to 8 .

Table 2. Quantitative characteristics of questioning activity's dynamics in children

\begin{tabular}{lcc}
\hline \multicolumn{1}{c}{ Characteristic } & September & May \\
\hline $\begin{array}{l}\text { Number of questions }(\mathrm{n}) \\
\begin{array}{l}\text { The average number of questions } \\
\text { (mean and standard deviation) }\end{array}\end{array}$ & 1248 & 1153 \\
\hline
\end{tabular}

${ }^{*} p<.001$ 
However, following N. B. Shumakova (1985), we do not regard this as a negative fact that signifies an obvious existing decline in children's question-asking behavior. We believe this decline is more likely caused by some positive changes in volitional verbal activity, which include a shift in the ratio of the productive questions to the identifying ones (increase in the number of productive questions from $47.2 \%$ to $54 \%$ ) and an increase in the number of children capable of choosing their own search action strategy independently (from $5.7 \%$ to $9.7 \%$ ), as shown in table 3 .

Table 3. Qualitative characteristics of questioning activity's dynamics in children

\begin{tabular}{lcccc}
\hline \multicolumn{1}{c}{ Characteristic } & September & May & $\mathbf{z}$ & P \\
\hline $\begin{array}{l}\text { Proportion of productive questions (\%) } \\
\begin{array}{l}\text { Proportion of children able to establish } \\
\text { direction of search actions (\%) }\end{array}\end{array}$ & 47.2 & 54.0 & 1.10 & .27 \\
\hline
\end{tabular}

Furthermore, questions aimed at discovering the information about the structure and configuration of the object (What parts does it consist of? What is it made of/from?) were more frequent, as were variation of question wording and including in the search algorithm the questions that had not been included in the given sequence (e.g., «What is its width?», «How long is it?», «What is it to the touch?» and «How much does it weigh?). At the same time, because no teaching activity had been targeted at developing question-asking behavior as a form of cognitive activity, positive changes were noticed mainly in those children whose possibilities by the time of the test's first sample were within their proximal realization, i.e., in the zone of proximal development.

The second set of diagnostics showed the highest positive dynamics at the optimal and reproductive levels (75\% increase and 33.9\% decrease, respectively). Additionally, the drift of the examinees was noted within the adjacent levels, mainly within the adjacent variations of the cognitive activity. For example, all the 18 firstgraders that moved from the efficiently stimulated level to the optimal level first demonstrated the peculiarities of the search activity characteristic of approach A. The overwhelming majority of them (15 children $-83.3 \%)$ could not independently work out a strategy to search for information about the unknown object during the second examination, although they succeeded in their productive search after being once suggested a list of questions. 19 examinees drifted from the third, or reproductive, level up to the second level, with most of them $(68.4 \%-$ 13 schoolchildren) demonstrating the needed data search peculiarities specific for approach $\mathrm{C}$ and $31.6 \%$ demonstrating the peculiarities for approach $\mathrm{B}$. In contrast, the remaining number of children did not show any notable positive changes.

\section{Conclusion}

The diagnostic methodology of question-asking behavior as a form of cognitive activity that we have worked out and the findings that we achieved using this methodology highlight common and variable peculiarities of how this type of activity in children manifests, as well as actual and potential possibilities of its development. 
The research has established that an overwhelming majority of the questions asked by the first-graders are search questions, half of which turned out to be efficient in finding information about the unknown object. At the same time, a lack of initiative in asking questions in the situation requiring volitional question wording was noticed.

Five levels of question-asking behavior as a form of cognitive activity were revealed, from optimally realized age potential to its actual absence (optimal, effectively stimulated, reproductive, inactive, lack of cognitive activity), each with their corresponding common and variable peculiarities of the studied sphere. It was discovered that only one child out of six or seven can formulate their own strategy for seeking necessary information about the unknown object and is inclined to ask questions that lead to discovering the information about the unknown in a problem situation. In other cases, to achieve an objective result, children had to be provided with help ranging from minimal stimulation to a joint generalization of the found information and even to direct prompts.

The analysis of the dynamics of the question-asking behavior throughout a school year revealed a tendency towards some positive changes. That is, why primary school children need psychological and pedagogical scaffolding aimed at developing a question-asking behavior as a form of cognitive activity to achieve a possible age potential in development.

\section{Limitations}

The given research was aimed at studying the peculiarities of question-asking behavior as a form of cognitive activity in first-year schoolchildren. To obtain a complete scientific conception of this form of cognitive activity it is necessary to study children of other age groups regarding the gender factor and different primary school curricula.

\section{References}

Alves, P. F. (2014). Vygotsky and Piaget: Scientific concepts. Psychology in Russia: State of the Art, 7(3), 24-34. doi: 10.11621/pir.2014.0303

Babich, N. (1984). Razvitie voprosov u doshkolnikov [Questions development in preschoolers]. Voprosy psikhologii [Issues in Psychology], 3, 67-74.

Baranova, E. A. (2009). Osobennosti voprositelnoi aktivnosti doshkolnikov i mladshikh shkolnikov [Features of interrogative activity in preschoolers and junior schoolchildren]. Psikhologicheskaya nauka i obrazovanie [Psychological Science and Education], 2. Retrieved from: http://psyedu.ru/journal/2009/2

Craft, A., Cremin, T., Hay, P., \& Clack, J. (2014). Creative primary schools: developing and maintaining pedagogy for creativity. Ethnography and Education, 9(1), doi: 10.1080/17457823.2013.828474.

Craft, A., McConnon, L., \& Matthews, A. (2012). Child-initiated play and professional creativity: Enabling four-year-olds' possibility thinking. Thinking Skills and Creativity, 7(1), 48-61. doi:10.1016/j.tsc.2011.11.005.

Cremin, T., Chappell, K., \& Craft, A. (2013). Reciprocity between narrative, questioning and imagination in the early and primary years: Examining the role of narrative in possibility thinking. Thinking Skills and Creativity, 9, 135-151. doi: 10.1016/j.tsc.2012.11.003 
Dillon, J. T. (1982). The effect of questions in education and other enterprises. Journal of Curriculum Studies, 14(2), 127-152. doi: 10.1080/0022027820140203.

Drovnikov, A. S., Nikolaev, E. L., Afanasev, A. S., Ivanov, V. N., Petrova, T. N., Tenyukova, G. G., Maksimova, N. L., \& Povshednaya, F. V. (2016). Teachers professional competence assessment technology In qualification improvement process. International Review of Management and Marketing, 6(1), 111-115

Eshach, H., Dor-Ziderman, Y., \& Yefroimsky, Y. (2014). Question asking in the science classroom: Teacher attitudes and practices. Journal of Science Education and Technology, 23(1), $67-81$.

Fahey, G. L. (1942). The questioning activity of children. The Pedagogical Seminary and Journal of Genetic Psychology, 60(2), 337-357. doi: 0.1080/08856559.1942.10534643.

Foster, C. (2011). Student-generated questions in mathematics teaching. The Mathematics Teacher, 105(1), 26-31. doi: 10.5951/mathteacher.105.1.0026

Gillies, R. M, Nichols, K., Burgh, G., \& Haynes, M. (2012). The effects of two strategic and metacognitive questioning approaches on children's explanatory behavior, problem-solving, and learning during cooperative, inquiry-based science. International Journal of Educational Research, 53, 93-106. doi:10.1016/j.ijer.2012.02.003.

Good, T. L., Slavings, R. L., Harel, K. H., \& Emerson, H. (1987). Student passivity: A study of question asking in K-12 classrooms. Sociology of Education, 60(3), 181-199. doi: $10.2307 / 2112275$.

Heath, S. B. (1982). Questioning at home and at school: A comparative study. Doing the ethnography of schooling: Educational anthropology in action, 102-131.

Henderson, R. W., \& Garcia, A. B. (1973). The effects of parent training program on the question-asking behavior of Mexican-American children. American Educational Research Journal, 10(3), 193-201. doi: 10.3102/00028312010003193.

Hurlock, E. B. (1956). Child Development. New York: McCraw-Hill Book Company.

Ishiwa, K., Sanjosé, V., \& Otero, J. (2013). Questioning and reading goals: Information-seeking questions asked on scientific texts read under different task conditions. British Journal of Educational Psychology, 83(3), 502-520. doi: 10.1111/j.2044-8279.2012.02079.x.

Jersild, A. T. (1968). Child Psychology. New York: Prentice-Hall.

Komarova, I. V. (2011). Rol voprosov v razvitii issledovatel'skikh sposobnostei detei doshkol'nogo i mladshego shkol'nogo vozrasta [The role of questions in development of research abilities in preschool and primary school children]. Vektor nauki Tol'yattinskogo gosudarstvennogo universiteta [Science Vector of Togliatti State University], 3(6), 164-168.

Krichevets, A. N. (2014). Vygotsky and intersubjectivity. Psychology in Russia: State of the Art, 7(3), 13-23. doi: 10.11621/pir.2014.0302

Ledford, C. J. W. , Saperstein, A. K., Cafferty, L. A., McClintick, S. H., \& Bernstein, E. M. (2015). Any questions? An application of weick's model of organizing to increase student involvement in the large-lecture classroom. Communication Teacher, 29(2), 116-128. doi: 10.1080/17404622.2014.1003309.

Maskill, R., \& deJesus, H. P. (1997). Pupils' questions, alternative frameworks and the design of science teaching. International Journal of Science Education, 19(7), 781-799. doi: 10.1080/0950069970190704.

McManis, L. D., \& Gunnewig, S. B. (2012). Finding the education in educational technology with early learners. Young Children, 67(3), 14-24.

Meyer, W.J., \& Shane, J. (1973). The form and function of children's questions. The Journal of Genetic Psychology: Research and Theory on Human Development, 123(2), 285-296. doi: 10.1080/00221325.1973.10532688. 
Mosher, F., \& Hornsby, J. (1971). O postanovke voprosov detmi [On asking questions by children]. In Issledovanie razvitiya poznavatenoi deyatelnosti [The study of cognitive activity development]. Moscow: Pedagogika.

Piaget, J. (1994). Rech i myshlenie rebenka [Speech and thinking of the child]. Moscow: Pedagogika-Press.

Ramonova, K. M. (1961). O psikhologicheskikh osobennostyakh lyuboznatelnosti detei doshkolnogo vozrasta [On the psychological characteristics of preschool children's curiosity]. Ordzhonikidze, USSR.

Raulston, T., Carnett, A., Lang, R., Tostanoski A., Lee, A., Machalicek, W., Sigafoos, J., O’Reilly, M.F., Didden, R., \& Lancioni, G.E. (2013). Teaching individuals with autism spectrum disorder to ask questions: A systematic review. Research in Autism Spectrum Disorders, 7(7), 866-878. doi: 10.1016/j.rasd.2013.03.008.

Rubinstein, M. (2008). Voprosy i ikh rol v umstvennom razvitii rebenka [Questions and their role in mental development of a child]. Doshkolnoe vospitanie [Preschool Education], 2, $7-14$.

Shumakova, N. B. (1985). Vopros v strukture poznavatelnoi aktivnosti [Question in structure of cognitive activity]. (Unpublished $\mathrm{PhD}$ thesis). Lomonosov Moscow State University, Moscow.

Sirbiladze, P. G. (1966). Poznavatelnye interesy doshkolnikov (ot 3-kh do 7-mi let) [Cognitive interests of preschool children (from 3 to 7 years)]. (Unpublished PhD thesis). Georgia, Tbilisi.

Sorokina, A. I. (1945). Motivy voprosov rebenka doshkolnogo vozrasta [Question's motives in preschool children]. (Unpublished $\mathrm{PhD}$ thesis). Russia, Leningrad.

Tarasova, S. A. (2004). Rol voprosov v ponimanii teksta mladshimi shkolnikami [The role of questions in text understanding by primary school children]. Voprosy psikhologii [Issues in Psychology], 4, 40-47.

van der Meij, H. (1990). Question asking: To know that you do not know is not enough. Journal of Educational Psychology, 82(3), 505-512. doi: 10.1037/0022-0663.82.3.505.

Verbitskaya, L. A., Malykh, S. B., Zinchenko, Y. P., \& Tikhomirova, T. N. (2015). Cognitive predictors of success in learning Russian. Psychology in Russia: State of the Art, 8(4), 64-73. doi: 10.11621/pir.2015.0408

Vygotsky, L. S. (1984). Problema vozrasta [The issue of age]. The collected works of L. S. Vygotsky in 6 volumes. Vol. 4. Moscow: Pedagogika.

Yushkov, A. E. (1997). Psikhologicheskie osobennosti stanovleniya detskoi voprositelnosti na urokakh- dialogakh $v$ nachalnoi shkole [Psychological features of formation of children's question activity on dialogue lessons in elementary school]. (Unpublished PhD thesis). Russia, Irkutsk.

Original manuscript received April 10, 2016 Revised manuscript accepted June 20, 2016

First published online March 31, 2017 